\title{
Effect of a Monascus sp. red yeast rice extract on germination of bacterial spores
}

3

\author{
Husakova Marketa ${ }^{1}$, Plechata Michaela1, Branska Barbora ${ }^{1}$, Patakova Petra ${ }^{{ }^{*}}$ \\ ${ }^{1}$ Department of Biotechnology, University of Chemistry and Technology Prague, Prague, \\ Czech Republic \\ * Correspondence: \\ Corresponding Author \\ petra.patakova@vscht.cz
}

Keywords: Monascus, red yeast rice, bacterial spores germination, nitrite, Clostridium beijerinckii, Bacillus subtilis

\begin{abstract}
The pink-red colour of traditional sausages (cured meat) is the result of nitrite addition and the formation of nitrosomyoglobin. However, the pleasant colour of processed meat products is a side effect of nitrite addition while the main anticipated goal is to suppress the germination of clostridial spores. The fungus Monascus is known as a producer of oligoketide pigments, which are used in Asian countries, especially in China, for colouring foods, including meat products. Although, different biological activities of Monascus pigments have been tested and confirmed in many studies, their effect on germination of bacterial spores has never been investigated. This study is focused on testing the activity of red yeast rice (RYR) extract, containing monascin, rubropunctatin, rubropunctamine complexes and monascuspiloin as the main pigments, on germination of Clostridium and Bacillus spores. It was found that addition of nitrite alone, at the permitted concentration, had no effect on spore germination. However, the combined effects of nitrite with $\mathrm{NaCl}$, tested after addition of pickling salt, was efficient in inhibiting the germination of $C$. beijerinckii spores but had no effect on B. subtilis spores. In contrast, total suppression of $C$. beijerinckii spore germination was reached after addition of RYR extract to the medium at a concentration of $2 \% \mathrm{v} / \mathrm{v}$. For B. subtilis, total inhibition of spore germination was observed only after addition of $4 \% \mathrm{v} / \mathrm{v}$ RYR extract to the medium containing $1.3 \% \mathrm{w} / \mathrm{w} \mathrm{NaCl}$.
\end{abstract}

\section{Introduction}

Red yeast rice (RYR) is rice fermented by the fungus Monascus, which is prepared for different applications using different Monascus species (for a recent review see Zhu et al., 2019). RYR has various synonyms such as hong-qu, beni-koji or ang-kak in languages of Asian countries, where the product is popular. In Europe, RYR is only permitted as a food supplement on the condition that it is prepared using Monascus purpureus and the preparation (food supplement) should contain $10 \mathrm{mg}$ of monacolin $\mathrm{K}$, administered daily, in order to guarantee the effect as described in the health claim "Monacolin $\mathrm{K}$ from red yeast rice contributes to the maintenance of normal blood cholesterol levels" (Commission Regulation (EU) No 432/2012 ). As a dose of $10 \mathrm{mg}$ of monacolin $\mathrm{K}$ corresponds to the lowest therapeutically effective dose of statins in prescription drugs, the required amount of monacolin $\mathrm{K}$ in RYR food supplements was reconsidered by the EFSA Panel on Food Additives and Nutrient Sources added to Food (ANS) in 2018 (EFSA Panel, 2018) but with no clear conclusion. Nevertheless, the main concern associated with the use of RYR is its potential contamination with citrinin, a mycotoxin whose 
toxicological effects on people have not been fully elucidated (de Oliveira Filho et al., 2017). By the Commission Regulation (EU) 2019/1901, the maximum tolerated citrinin concentration in RYR was set to $100 \mu \mathrm{g} / \mathrm{kg}$.

The fungus Monascus is especially known for its production of red pigments, which are used in certain Asian countries, such as China, Japan or Philippines, for food colouring. As the colour red is associated with many different fruits, vegetables and meat products, Monascus pigments are mostly used for colouring cakes or other sweet products, fruit yoghurts or other fermented milk products and processed meat. The suitability of Monascus pigments for colouring meat products, particularly with regard to colour, texture, smell and other sensory parameters of the products, has already been proven in the scientific literature (Leistner et al., 1991; Fabre et al., 1993; Yu et al., 2015; Seong et al., 2017). In addition, inhibitory effects of Monascus pigments or Monascus extracts on vegetative bacterial cells e.g. Staphylococcus aureus, Escherichia coli, Bacillus subtilis ((Kim et al., 2006; Vendruscolo et al., 2014; Zhao et al., 2016) have been demonstrated. In addition, the safety of Monascus pigments for human consumption has been confirmed in several studies (Bianchi, 2005; Yu et al., 2008; Mohan Kumari et al., 2009).

The aim of the study was to test whether an ethanol extract of red yeast rice, having a red colour and containing a mixture of Monascus pigments but without citrinin and monacolin K, might suppress germination of bacterial spores. In traditional food processing, nitrite salts have been added to meat products in order to achieve total inhibition of germination of Clostridium botulinum spores. Nitrite salts are also responsible for the pleasing red colour of processed meat products, caused by the formation of nitrosomyoglobin. In the work described for the first time here, Clostridium beijerinckii and Bacillus subtilis spores were used as models of anaerobic and aerobic bacterial spore formers, respectively.

\section{Material and Methods}

\subsection{RYR preparation}

Monascus sp. DBM 4361, isolated from a nonsterile dried red fermented rice sample, was maintained on Potato-Dextrose agar (VWR Chemicals) slants at $4^{\circ} \mathrm{C}$. The strain was deposited at the Department of Biochemistry and Microbiology (DBM), University of Chemistry and Technology Prague.

An amount of rice (Giana, Thailand) (150 g) was washed with hot water, then boiled for 1 minute. The rice was evenly divided into three autoclavable plastic bags, which were closed with a metal ring and a cotton plug. The bags were placed in a beaker sealed with aluminium foil and sterilized at $121{ }^{\circ} \mathrm{C}$ for 20 minutes. Sterilization was repeated after 24 hours to eliminate contamination by spore-forming bacteria. Spores from the Monascus culture (mixture of ascospores and conidia, because the strain formed both asexual and sexual spores, see Fig. 1) were transferred to sterile water using a sterile loop. The sterile rice in the bags was inoculated with $5 \mathrm{~mL}$ of the spore suspension. Cultivation of the fungus on rice was performed for 10 days at $30^{\circ} \mathrm{C}$. The rice was mixed by hand daily.

\subsection{Extraction of pigments, $\mathbf{p H}$ estimation}

The RYR (Fig.2) (5 g) was extracted with $25 \mathrm{~mL}$ of $70 \%$ ethanol and distilled water in $250 \mathrm{~mL}$ Erlenmeyer flasks for $1 \mathrm{~h}$, at $30^{\circ} \mathrm{C}$, with shaking (laboratory shaker Infors, $100 \mathrm{rpm}$ ). The mixture was then filtered through Whatman 1 filter paper. Pooled ethanol extracts from 3 flasks were concentrated using a rotary vacuum evaporator (Boeck) (max. temperature $55^{\circ} \mathrm{C}$ ), so that all ethanol was evaporated. The remaining water extract contained insoluble pigmented particles, which were collected by filtration and dissolved in $96 \%$ ethanol. The resulting ethanol 
extract was used for all microbiological assays and was analyzed by HPLC. The $\mathrm{pH}$ of pooled water extracts from 3 flasks was measured and shown to be 4.9.

\subsection{RYR extract analysis \\ 2.3.1 Spectrophotometric analysis of the RYR extract}

The RYR extract was diluted 200-fold with $96 \%$ ethanol to adjust the absorbance to $0.1-1.0$ at $330-600 \mathrm{~nm}$. The absorbance of the sample was detected using a spectrophotometer (Varian Cary 50 Bio). The results were represented as an absorbance spectrum or as an absorbance value at a selected wavelength, the dilution factor being taken into consideration. As a blank, $96 \%$ ethanol was used.

\subsubsection{UHPLC analysis of pigments, citrinin and monacolin $\mathrm{K}$}

UHPLC (Agilent Technologies 1260 Infinity II) was used to determine Monascus pigments, citrinin and monacolin K. The following conditions were used: Kinetex Polar C18, 100A, $150 \mathrm{x}$ $4.6 \mathrm{~mm}$ column; the mobile phase: $0.025 \% \mathrm{H}_{3} \mathrm{PO}_{4}$ in water:acetonitrile at a ratio of $60: 40$; isocratic elution at a flow rate $1.5 \mathrm{~mL} / \mathrm{min}$; injection volume $5 \mu \mathrm{L}$. For determination of yellow, orange and red pigments, a photodiode detector set at 390, 470 and $500 \mathrm{~nm}$ resp. was used. The presence of monacolin $\mathrm{K}$ was detected at $237 \mathrm{~nm}$. For the determination of the mycotoxin citrinin, the fluorescence detector setting was $331 \mathrm{~nm}$ for excitation and $500 \mathrm{~nm}$ for emission. For analysis, the extract sample was diluted 10-fold with $96 \%$ ethanol.

The standards of mycotoxin citrinin (Sigma-Aldrich), yellow pigment monascin (Sigma-Aldrich), and orange pigment rubropuctatin (1717 CheMall Corporation) were used as reference samples. A rubropunctamine laboratory standard was prepared from the rubropunctatin standard by reaction with $\mathrm{NH}_{4} \mathrm{OH}$ (Penta). Unknown yellow, orange and red pigments were identified based on their absorption spectra and quantified as equivalents to their respective standards, i.e. monascin, rubropunctatin and rubropunctamine. For identification of individual compounds in the chromatogram, previous results (Patrovsky et al., 2019) were used.

\subsubsection{HPLC-MS analysis}

HPLC-HRMS (Accella 600 Thermo Scientific) was used to determine molecular weights of the Monascus pigments. The following conditions were used: Luna Omega Polar $1.6 \mu \mathrm{m}, 50$ x 2.1 mm Phenomenex column; mobile phase: $0.1 \% \mathrm{HCOOH}$ in water:methanol; gradient elution (A:B in ratio from 90:10 to 5:95) at a flow rate of $300 \mu \mathrm{L} / \mathrm{min}$; injection volume $5 \mu \mathrm{L}$; ESI-positive mode; LTQ Orbitrap Velos mass analyzer (Thermo Scientific). For the analysis, the extract sample was diluted 200 -fold with a solution of $90 \%$ water $10 \%$ methanol.

\subsection{Spore germination assays}

\subsubsection{Preparation of spore suspensions}

Clostridium beijerinckii NCIMB 8052 and Bacillus subtilis DBM 3006 were stored in the form of spore suspensions in sterile distilled water at $4{ }^{\circ} \mathrm{C}$. Spores of $C$. beijerinckii NCIMB 8052 were obtained after $48 \mathrm{~h}$ incubation of the culture in $250 \mathrm{~mL}$ Erlenmeyer flasks containing 100 $\mathrm{mL}$ of TYA medium in an anaerobic chamber (Concept 400, Ruskinn Technology, UK) at 37 ${ }^{\circ} \mathrm{C}$. TYA medium contained in $\mathrm{g} / \mathrm{L}$ : glucose 40, yeast extract (Merck) 2, tryptone (Sigma Aldrich) 6 , potassium dihydrogenphosphate 0.5 , ammonium acetate 3 , magnesium sulfate heptahydrate, 0.3 , ferrous sulfate heptahydrate 0.01 ; the $\mathrm{pH}$ of the medium was adjusted prior 
to sterilization in the autoclave $\left(20 \mathrm{~min}, 121{ }^{\circ} \mathrm{C}, 0.1 \mathrm{MPa}\right)$ to 6.8 . Spores of B. subtilis DBM 3006 were obtained after $48 \mathrm{~h}$ incubation of the culture in $250 \mathrm{~mL}$ Erlenmeyer flasks containing $50 \mathrm{~mL}$ of MP broth shaken on a rotary shaker (New Brunswick Scientific) at $300 \mathrm{rpm}$ and 30 ${ }^{\circ} \mathrm{C}$. MP broth contained in $\mathrm{g} / \mathrm{L}$ : meat extract (Roth) 3, peptone (Roth) 5; the $\mathrm{pH}$ of the medium was adjusted prior to sterilization in the autoclave $\left(20 \mathrm{~min}, 121^{\circ} \mathrm{C}\right)$ to 7.0 . Salts, $\mathrm{HCl}$ and $\mathrm{NaOH}$ for medium preparation and $\mathrm{pH}$ adjustment were purchased from Penta, Czech Republic. After cultivation, spores of both bacterial cultures were harvested by centrifugation (Hettich MIKRO 220R) for $5 \mathrm{~min}, 5000 \mathrm{rpm}$, at $4{ }^{\circ} \mathrm{C}$. Spores were washed with sterile water, centrifuged under the same conditions and re-suspended in $20 \mathrm{~mL}$ of sterile water. Finally, the spore suspension was pipetted in $1 \mathrm{~mL}$ portions into Eppendorf tubes, which were stored at $4^{\circ} \mathrm{C}$. All spore handling was performed under aseptic conditions using sterile tools and materials. Spore concentrations were estimated by flow cytometry (Branska et al., 2018) to be $2.10^{8}$ spores $/ \mathrm{mL}$ and $8.10^{8}$ spores $/ \mathrm{mL}$ for $C$. beijerinckii and B. subtilis, respectively. Prior to inoculation of medium for germination assays, spore suspensions were heat shocked $\left(80^{\circ} \mathrm{C}\right.$ for $30 \mathrm{~s}$ followed by cooling on ice for $2 \mathrm{~min}$ ) to accelerate germination.

\subsubsection{C. beijerinckii germination assay}

149 The cultivation tests were performed in $20 \mathrm{~mL}$ test tubes containing $9.8 \mathrm{~mL}$ of medium inoculated with $0.2 \mathrm{~mL}$ heat shocked spore suspension of $C$. beijerinckii. Unmodified TYA medium was used as a positive control. The cultivation tests were performed in triplicate, in the anaerobic chamber, at $37^{\circ} \mathrm{C}$ for $48 \mathrm{~h}$. Different combinations of agents were added to the TYA medium to test their effect on spore germination; see Table I.

\subsubsection{B. subtilis germination assay}

The cultivation tests were performed on microcultivation plates using the Bioscreen $\mathrm{C}$ device (LabSystem) with intermittent shaking (30 seconds every 3 minutes) at $30{ }^{\circ} \mathrm{C}$ for $24 \mathrm{~h}$. Each well of the plate was filled with $196 \mu \mathrm{L}$ of medium and $4 \mu \mathrm{L}$ of $B$. subtilis heat shocked spore suspension. In each well, optical density was measured at $600 \mathrm{~nm}$, every 30 minutes. Unmodified MP medium was used as a positive control. Each cultivation test was performed in 6 wells. Different combinations of agents were added to the MP medium to test their effect on spore germination, see Table II.

\section{Results}

\section{3.1. C. beijerinckii germination}

164 Clostridium beijerinckii spores were chosen as a model substituting for Clostridium botulinum 165 spores because both species belong to the same Cluster I (sensu stricto) of 166 the Clostridium genus (Cruz-Morales et al., 2019). Heat-shocked spores of $C$. beijerinckii were inoculated to $2 \%$ by volume to the medium in test tubes and were allowed to germinate under anaerobic conditions. The TYA medium and the inoculation ratio were chosen to guarantee reliable spore germination based on previous experience with the strain (Kolek et al., 2016). The compositions of different media were designed (see Table I) to be able to compare any effect of nitrite salts with the potential effect of the RYR extract, not containing citrinin and monacolin $\mathrm{K}$. Nitrites are only allowed to be added to meat products in a mixture with sodium chloride in the form of $\mathrm{NaNO}_{2}$ (E249 food additive) or $\mathrm{KNO}_{2}$ (E250 food additive), in an amount not exceeding $150 \mathrm{mg}$ of nitrite per $1 \mathrm{~kg}$ of a standard meat product (only in some national specialities produced in different EU countries can the amount of nitrite be higher, up to $300 \mathrm{mg} / \mathrm{kg}$, for certain salamis and bacons and up to $500 \mathrm{mg} / \mathrm{kg}$ for herrings and sprouts); for 
a survey of rules valid in the EU for the addition of nitrite/nitrate to meat products, see Honikel,

1782008.

179 Nitrite, in the form of $\mathrm{NaNO}_{2}$, was added to the culture, either independently or as a component

180 of Praganda nitrite pickling salt. In addition, $\mathrm{NaNO}_{3}$ (E251 food additive) was tested because

181 its addition is permitted and applied in cheeses to a maximum concentration of $150 \mathrm{mg} / \mathrm{kg}$, with

182 the aim of suppressing germination of Clostridium butyricum spores. While even the addition

183 of $\mathrm{NaNO}_{2}$ or $\mathrm{NaNO}_{3}$ alone at a concentration of $300 \mathrm{mg} / \mathrm{kg}$ had no effect on the germination of

184 C. beijerinckii spores, addition of nitrite pickling salt to the recommended concentration for

185 various products i.e. $2 \%(\mathrm{w} / \mathrm{w})$ of the pickling salt or $1.3 \%(\mathrm{w} / \mathrm{w})$ as recommended for products

186 with low salt content, resulted in total inhibition of spore germination (see Table III, experiment

187 codes $\mathrm{TYA}+\mathrm{NaNO}_{2} ; \mathrm{TYA}+\mathrm{NaNO}_{3} ; \mathrm{TYAN} 2$ and TYAN1). As Clostridium beijerinckii is

188 sensitive to high concentrations of $\mathrm{NaCl}$ (Branska et al., 2020), the independent effect of $\mathrm{NaCl}$

189 addition was also tested. While addition of $\mathrm{NaCl}$ to $2 \% \mathrm{w} / \mathrm{w}$ suppressed spore germination, 1.3

$190 \%$ w/w did not reliably suppress germination in all cases (see Table III, code TYAS2 and

191 TYAS1).

192 Addition of $2 \%$ v/v RYR extract was tested with standard TYA medium and with medium 193 containing $1.3 \% \mathrm{w} / \mathrm{w} \mathrm{NaCl}$; addition of ethanol to the same concentration $(2 \% \mathrm{v} / \mathrm{v})$ was tested 194 as a control (Table III, codes TYA+RYR, TYA+ Et, TYAS1 +RYR, TYAS1 +Et ). While 195 addition of the RYR extract suppressed spore germination, ethanol did not. The RYR extract 196 did not contain citrinin but, because it is known that citrinin has certain antimicrobial properties, 197 the citrinin effect was tested at a concentration of $2000 \mu \mathrm{g} / \mathrm{kg}$. This concentration of citrinin 198 reflects the amount that was EU-permitted in an RYR food supplement until 2019, after which 199 the limit was reconsidered and adjusted to $100 \mu \mathrm{g} / \mathrm{kg}$. Citrinin was tested alone or in 200 combination with RYR (Table III, codes TYA+cit, TYA+ RYR + cit).

201 Typical test tube growth characteristics of $C$. beijerinckii exhibiting high turbidity, foam and 202 development of bubbles of fermentation gas (mixture of $\mathrm{CO}_{2}$ and hydrogen) as well as colour 203 of the medium after addition of the RYR extract are shown in Fig.3. Only the ability to grow 204 (indicated as + or -) was tested in the C. beijerinckii germination assay. Determination of optical 205 density was not performed in order to not disturb the anaerobic atmosphere. Changed

\subsection{B.subtilis germination}

To follow the growth of spore formers after germination, Bacillus subtilis germination assays were performed, even if these spores do not normally occur in meat products (Fig.4). Nevertheless, B. subtilis spores are more resistant to adverse environmental effects in comparison with the $C$. beijerinckii spores, therefore the design of experiments had to be different (Table II) in order to inhibit germination. Total suppression of spore germination was achieved only after addition of the RYR extract to $4 \% \mathrm{v} / \mathrm{v}$ in medium containing $1.3 \% \mathrm{w} / \mathrm{w}$ $\mathrm{NaCl}$ (Fig. 4D, MPS1+RYR2). In other cases, growth was always detected, even if, in some cases, germination was delayed by up to $10 \mathrm{~h}$ (Fig.4B, MP+ RYR2). Surprisingly, addition of nitrite pickling salt to the recommended $2 \% \mathrm{w} / \mathrm{w}$ did not inhibit germination of the spores (Fig.4A, MPN2).

\subsection{RYR extract analysis}


The absorption spectrum of the RYR extract is shown in Fig. 5. Values of absorption found by spectrophotometric analysis at 390, 470 and $500 \mathrm{~nm}$, corresponding to assumed absorption maxima of yellow, orange and red pigments, were 98, 58 and 70, respectively. Monascin (yellow), rubropunctatin (orange) and rubropunctamine (red) were identified in the RYR extract by UHPLC analysis, (Fig. 6) while their analogs with seven carbon side chains i.e. ankaflavin (yellow), monascorubrin (orange) and monascorubramine (red) were not detected; neither was citrinin or monacolin $\mathrm{K}$. The detected yellow pigments were quantified as monascin equivalents $(1220 \mathrm{mg} / \mathrm{L})$, orange pigments as rubropunctatin equivalents $(336 \mathrm{mg} / \mathrm{L})$ and red pigments as rubropunctamine equivalents $(408 \mathrm{mg} / \mathrm{L})$. However, other compounds labelled as yellow I and red I-VI were found and for their putative identification, HPLC-MS analysis and already published m/z data on different Monascus metabolites were used (for survey of the Monascus pigments data see Chen et al., 2019). While red I-red VI are probably rubropunctamine derivatives that were formed by the reaction of rubropunctatin with available amino group containing compounds, yellow I was identified as monascuspiloin (m/z 360.4). The RYR extract was added to TYA and MP medium to concentrations of 2 and $4 \% \mathrm{v} / \mathrm{v}$, respectively, and the concentrations of pigments added to the medium are shown in Table IV. The water extract of the RYR had a $\mathrm{pH} 4.9$ but the $\mathrm{pH}$ of TYA or MP medium was 6.8 or 7.0. To determine whether the pigment profile was the same as the original RYR extract in the culture medium, samples of medium containing RYR mixed in a $1: 1$ volume ratio were analyzed by UHPLC. As expected, rubropunctatin was absent in the samples while monascin and monascuspiloin remained (data not shown).

\section{Discussion}

Nitrite and nitrate addition to meat products, together with $\mathrm{NaCl}$, is traditional in European countries and is considered to be of low impact on human health even if cancerogenic nitrosamines can be formed in the acidic environment of the human stomach after ingestion of nitrite/nitrate containing food (Honikel, 2008; EFSA Panel, 2017). It is believed that the benefits of stable red colour, antioxidant and antimicrobial effects of nitrite/nitrate outweigh potential risks. Nevertheless, within this study it was found that addition of nitrite or nitrate alone, to the permitted concentration, did not suppress spore germination. Similar observations were documented in other studies for the germination of Clostridium perfringens (Labbe and Duncan, 1970), Clostridium botulinum (Sofos et al., 1979) or cheese associated clostridia including C. beijerinckii (Ávila et al., 2014) spores. However, combined effect of nitrite with $\mathrm{NaCl}$ tested after addition of the pickling salt both at the standard concentration of pickling salt $(2 \% \mathrm{w} / \mathrm{w})$ and at the level recommended for low salt products $(1.3 \% \mathrm{w} / \mathrm{w})$ was efficient in inhibiting the germination of $C$. beijerinckii spores but had no effect on germination of $B$. subtilis spores. However, total suppression of germination of $C$. beijerinckii spores was also achieved after addition of RYR extract to TYA medium, to a concentration of $2 \% \mathrm{v} / \mathrm{v}$ while total suppression of germination of $B$. subtilis spores was only achieved after addition of $4 \%$ v/v RYR extract to MP containing $1.3 \% \mathrm{w} / \mathrm{w} \mathrm{NaCl}$. These results suggest that the RYR extract might substitute for nitrite salts in inhibiting germination of Clostridium spores.

264 Within the study, the ethanol effect on bacterial spore germination was confirmed (Setlow et al., 2002) as well as the effect of $\mathrm{NaCl}$ (Nagler et al., 2014) and the synergistic effect of different agents (Nerandzic et al., 2015). Even if the RYR extract did not contain citrinin, its effect at $2000 \mu \mathrm{g} / \mathrm{L}$ (the permitted concentration of citrinin in RYR food supplements in the EU until 2019) was tested, but if applied independently, had no effect on spore germination. level but it might be $M$. pilosus because its characteristics, i.e., no citrinin production and 
formation of both conidia and ascospores, corresponds with an already described strain, M. pilosus MS-1, also isolated from the red yeast rice (Feng et al., 2016). The absence of citrinin production was also found in M. pilosus NBRC4520 (Higa et al., 2020). In the RYR extract, there were found three of six iconic Monascus pigments; in particular monascin, rubropunctatin and rubropunctamine, together with rubropunctamine complexes with different amino groupcontaining compounds and monascuspiloin, a yellow pigment with a structure similar to monascin that has already been described as the metabolite of M. pilosus M93 (Chen et al., 2012). Interestingly, only monascin and rubropunctatin, i.e. pigments with a shorter five carbon side chain, but not their analogs (ankaflavin and monascorubrin with seven carbon side chains) were found. During the biosynthesis of pigments by M. ruber M7 (Chen et al., 2017), MrPigJ and $\mathrm{MrPigK}$ subunits of fatty acid synthase were found as the proteins responsible for the integration of $\beta$-ketooctanoic or $\beta$-ketodecanoic acid moieties into the structure of the pigments. However, the selection of the particular fatty acid moiety was considered to be random or not yet understood. Homologous genes to MrPigJ, MrPigK were described in M. purpureus (MpFasA2, MpFasB2) (Balakrishnan et al., 2013) and other Monascus strains (Guo et al., 2019) but not in M. pilosus. Even in the newest review of azaphilone biosynthesis (Pavesi et al., 2021), factors that determine the selection of particular fatty acid moieties are not described.

For the detection of substances in Monascus extracts, it is not sufficient to use the absorption spectrum or to determine absorbance values of the extract at the absorption maxima of individual pigments, typically at 390,470 and $500 \mathrm{~nm}$. It is really necessary to analyze extracts by HPLC or other analytical method (cf. Fig.5 and Fig.6). Notwithstanding, the determination of individual compounds in Monascus extracts is difficult because it depends inter alia on the $\mathrm{pH}$ of the extract (Shi et al., 2016).

After the addition of the RYR extract to medium, the original $\mathrm{pH}$ of the RYR extract changed from 4.9 to 6.8 or 7.0, resulting in the reaction of rubropunctatin with available amino group containing compounds, such as amino acids. It is possible that this reaction might contribute to the suppression of spore germination in the medium. Amino acids such as L-alanine or glycine are known germinants (factors stimulating germination) of bacterial spores (Setlow, 2014; Bhattacharjee et al., 2016) and if their amount was decreased it might affect germination. In addition, it was reported that Monascus red pigment derivatives had pronounced effects on the growth of Gram positive bacteria, including B. subtilis (Kim et al., 2006). The assumed cause of inhibition was adsorption of pigment derivatives onto the surface of cells, limiting oxygen uptake, where their MIC values were found to be 4-8 $\mu \mathrm{g} / \mathrm{L}$. In our assay, rubropunctatin and a mixture of red pigment derivatives, to concentrations of $13.4 \mathrm{mg} / \mathrm{L}$ and $16.4 \mathrm{mg} / \mathrm{L}$, respectively, were added to MP culture medium used for outgrowth of $B$. subtilis spores (see Table IV) and B.subtilis was cultured under aerobic conditions; the above aerobic effect (Kim et al., 2006) might also apply here. Orange and red Monascus pigments, at concentrations of 10-20 mg/L, inhibited growth of Gram negative bacteria (Vendruscolo et al., 2014), which corresponds with our findings. Yellow pigments monascin and monascuspiloin, detected in the RYR, , were found to have anticancerogenic effects (Akihisa et al., 2005; Chen et al., 2012; Chiu et al., 2012) but their antibacterial effect was never tested.

\section{Acknowledgement}

313 Financial support from specific university research (MEYS No 8-SVV/2021).

\section{References}


Commission Regulation (EU) 2019/1901 of 7 November 2019 amending Regulation (EC) No $1881 / 2006$ as regards maximum levels of citrinin in food supplements based on rice fermented with red yeast Monascus purpureus.

Commission Regulation (EU) No 432/2012 of 16 May 2012 establishing a list of permitted health claims made on foods, other than those referring to the reduction of disease risk and to children's development and health.

(ANS), E.P.o.F.A.a.N.S.a.t.F. (2018). "Scientific opinion on the safety of monacolins in red yeast rice", in: EFSA J.).

Akihisa, T., Tokuda, H., Ukiya, M., Kiyota, A., Yasukawa, K., Sakamoto, N., et al. (2005). Anti-tumor-initiating effects of monascin, an azaphilonoid pigment from the extract of Monascus pilosus fermented rice (red-mold rice). Chem Biodivers 2(10), 1305-1309. doi: 10.1002/cbdv.200590101.

Ávila, M., Gómez-Torres, N., Hernández, M., and Garde, S. (2014). Inhibitory activity of reuterin, nisin, lysozyme and nitrite against vegetative cells and spores of dairy-related Clostridium species. Int J Food Microbiol 172, 70-75. doi: 10.1016/j.ijfoodmicro.2013.12.002.

Balakrishnan, B., Karki, S., Chiu, S.-H., Kim, H.-J., Suh, J.-W., Nam, B., et al. (2013). Genetic localization and in vivo characterization of a Monascus azaphilone pigment biosynthetic gene cluster. Appl Microbiol Biotechnol 97(14), 6337-6345. doi: 10.1007/s00253-0134745-9.

Bhattacharjee, D., McAllister, K.N., and Sorg, J.A. (2016). Germinants and their receptors in Clostridia. J Bacteriol 198(20), 2767-2775. doi: 10.1128/JB.00405-16.

Bianchi, A. (2005). Extracts of Monascusus purpureus beyond statins - Profile of efficacy and safety of the use of extracts of Monascus purpureus. Chin J Integr Med 11(4), 309-313. doi: 10.1007/BF02835797.

Branska, B., Fořtová, L., Dvořáková, M., Liu, H., Patakova, P., Zhang, J., et al. (2020). Chicken feather and wheat straw hydrolysate for direct utilization in biobutanol production. Renewable Energy 145, 1941-1948. doi: https://doi.org/10.1016/j.renene.2019.07.094.

Branska, B., Pechacova, Z., Kolek, J., Vasylkivska, M., and Patakova, P. (2018). Flow cytometry analysis of Clostridium beijerinckii NRRL B-598 populations exhibiting different phenotypes induced by changes in cultivation conditions. Biotechnol Biofuels 11(1), 99. doi: 10.1186/s13068-018-1096-x.

Chen, R.-J., Hung, C.-M., Chen, Y.-L., Wu, M.-D., Yuan, G.-F., and Wang, Y.-J. (2012). Monascuspiloin induces apoptosis and autophagic cell death in human prostate cancer cells via the Akt and AMPK signaling pathways. J Agric Food Chem 60(29), 71857193. doi: 10.1021/jf3016927.

Chen, W., Chen, R., Liu, Q., He, Y., He, K., Ding, X., et al. (2017). Orange, red, yellow: biosynthesis of azaphilone pigments in Monascus fungi. Chem Sci 8(7), 4917-4925. doi: $10.1039 / \mathrm{c} 7 \mathrm{sc} 00475 \mathrm{c}$.

Chen, W., Feng, Y., Molnár, I., and Chen, F. (2019). Nature and nurture: confluence of pathway determinism with metabolic and chemical serendipity diversifies Monascus azaphilone pigments. Natural Product Reports 36(4), 561-572. doi: 10.1039/C8NP00060C.

Chiu, H.-W., Fang, W.-H., Chen, Y.-L., Wu, M.-D., Yuan, G.-F., Ho, S.-Y., et al. (2012). Monascuspiloin enhances the radiation sensitivity of human prostate cancer cells by stimulating endoplasmic reticulum stress and inducing autophagy. PloS one 7(7), e40462.

Cruz-Morales, P., Orellana, C.A., Moutafis, G., Moonen, G., Rincon, G., Nielsen, L.K., et al. (2019). Revisiting the Evolution and Taxonomy of Clostridia, a Phylogenomic Update. Genome Biology and Evolution 11(7), 2035-2044. doi: 10.1093/gbe/evz096. 
de Oliveira Filho, J.W.G., Islam, M.T., Ali, E.S., Uddin, S.J., Santos, J.V.d.O., de Alencar, M.V.O.B., et al. (2017). A comprehensive review on biological properties of citrinin. Food Chem Toxicol 110, 130-141. doi: https://doi.org/10.1016/j.fct.2017.10.002.

EFSA Panel on Food Additives Nutrient Sources added to Food (ANS) (2017). Re-evaluation of potassium nitrite (E 249) and sodium nitrite (E 250) as food additives. EFSA J 15(6), e04786. doi: 10.2903/j.efsa.2017.4786.

Fabre, C.E., Santerre, A.L., Loret, M.O., Baberian, R., Pareilleux, A., Goma, G., et al. (1993). Production and food applications of the red pigments of Monascus ruber. J Food Sci 58(5), 1099-1102. doi: https://doi.org/10.1111/j.1365-2621.1993.tb06123.x.

Feng, Y., Chen, W., and Chen, F. (2016). A Monascus pilosus MS-1 strain with high-yield monacolin K but no citrinin. Food Science and Biotechnology 25(4), 1115-1122. doi: 10.1007/s10068-016-0179-3.

Guo, X., Li, Y., Zhang, R., Yu, J., Ma, X., Chen, M., et al. (2019). Transcriptional regulation contributes more to Monascus pigments diversity in different strains than to DNA sequence variation. World J Microbiol Biotechnol 35(9), 1-13. doi: 10.1007/s11274019-2711-0.

Higa, Y., Kim, Y.-S., Altaf-Ul-Amin, M., Huang, M., Ono, N., and Kanaya, S. (2020). Divergence of metabolites in three phylogenetically close Monascus species ( $M$. pilosus, $M$. ruber, and $M$. purpureus) based on secondary metabolite biosynthetic gene clusters. BMC Genomics 21(1), 679. doi: 10.1186/s12864-020-06864-9.

Honikel, K.-O. (2008). The use and control of nitrate and nitrite for the processing of meat products. Meat Sci 78(1), 68-76. doi: 10.1016/j.meatsci.2007.05.030.

Kim, C., Jung, H., Kim, Y.O., and Shin, C.S. (2006). Antimicrobial activities of amino acid derivatives of monascus pigments. FEMS Microbiol Lett 264(1), 117-124. doi: 10.1111/j.1574-6968.2006.00451.x.

Kolek, J., Branska, B., Drahokoupil, M., Patakova, P., and Melzoch, K. (2016). Evaluation of viability, metabolic activity and spore quantity in clostridial cultures during $\mathrm{ABE}$ fermentation. FEMS Microbiology Letters 363(6). doi: 10.1093/femsle/fnw031.

Labbe, R.G., and Duncan, C.L. (1970). Growth from spores of Clostridium perfringens in the presence of sodium nitrite. Appl Microbiol 19(2), 353-359.

Leistner, L., Fink-Gremmels, J., and Dresel, J. (Year). "Monascus extract-A possible alternative to nitrite in meats", in: Proceedings of 37th International Congress of Meat Science and Technology), 1252-1256.

Mohan Kumari, H.P., Akhilender Naidu, K., Vishwanatha, S., Narasimhamurthy, K., and Vijayalakshmi, G. (2009). Safety evaluation of Monascus purpureus red mould rice in albino rats. Food Chem Toxicol 47(8), 1739-1746. doi: https://doi.org/10.1016/j.fct.2009.04.038.

Nagler, K., Setlow, P., Li, Y.-Q., and Moeller, R. (2014). High salinity alters the germination behavior of Bacillus subtilis spores with nutrient and nonnutrient germinants. Appl Environ Microbiol 80(4), 1314-1321. doi: 10.1128/AEM.03293-13.

Nerandzic, M.M., Sankar C, T., Setlow, P., and Donskey, C.J. (2015). A cumulative spore killing approach: Synergistic sporicidal activity of dilute peracetic acid and ethanol at low $\mathrm{pH}$ against Clostridium difficile and Bacillus subtilis spores. Open Forum Infect Dis 3(1). doi: 10.1093/ofid/ofv206.

Patrovsky, M., Sinovska, K., and Branska, B. (2019). Effect of initial pH, different nitrogen sources, and cultivation time on the production of yellow or orange Monascus purpureus pigments and the mycotoxin citrinin. Food Sci Nutr 7. doi: 10.1002/fsn3.1197.

Pavesi, C., Flon, V., Mann, S., Leleu, S., Prado, S., and Franck, X. (2021). Biosynthesis of azaphilones: a review. Nat Prod Rep. doi: 10.1039/D0NP00080A. 
Seong, P.N., Ba, H.V., Kim, Y.S., Kang, S.M., Cho, S.H., Kim, J.H., et al. (2017). Effects of additions of Monascus and laccaic acid on the colour and quality properties of nitritefree emulsion sausage during refrigerated storage. Korean J Food Sci Anim Resour 37(1), 10-17. doi: 10.5851/kosfa.2017.37.1.10.

Setlow, B., Loshon, C.A., Genest, P.C., Cowan, A.E., Setlow, C., and Setlow, P. (2002). Mechanisms of killing spores of Bacillus subtilis by acid, alkali and ethanol. J Appl Microbiol 92(2), 362-375. doi: 10.1046/j.1365-2672.2002.01540.x.

Setlow, P. (2014). Germination of spores of Bacillus species: what we know and do not know. J Bacteriol 196(7), 1297-1305. doi: 10.1128/JB.01455-13.

Shi, K., Chen, G., Pistolozzi, M., Xia, F., and Wu, Z. (2016). Improved analysis of Monascus pigments based on their $\mathrm{pH}$-sensitive UV-Vis absorption and reactivity properties. Food Addit Contam Part A 33(9), 1396-1401. doi: 10.1080/19440049.2016.1214289.

Sofos, J., Busta, F., and Allen, C. (1979). Sodium nitrite and sorbic acid effects on Clostridium botulinum spore germination and total microbial growth in chicken frankfurter emulsions during temperature abuse. Appl Environ Microbiol 37(6), 1103-1109. doi: 10.1128/AEM.37.6.1103-1109.1979.

Vendruscolo, F., Tosin, I., Giachini, A.J., Schmidell, W., and Ninow, J.L. (2014). Antimicrobial activity of Monascus pigments produced in submerged fermentation. $J$ Food Process Preserv 38(4), 1860-1865. doi: https://doi.org/10.1111/jfpp.12157.

Yu, C.-C., Wang, J.-J., Lee, C.-L., Lee, S.-H., and Pan, T.-M. (2008). Safety and mutagenicity evaluation of nanoparticulate red mold rice. J Agric Food Chem 56(22), 11038-11048. doi: $10.1021 /$ jf801335u.

$\mathrm{Yu}, \mathrm{X} ., \mathrm{Wu}, \mathrm{H}$., and Zhang, J. (2015). Effect of Monascus as a nitrite substitute on colour, lipid oxidation, and proteolysis of fermented meat mince. Food Sci Biotechnol 24(2), 575581. doi: 10.1007/s10068-015-0075-2.

Zhao, G.-P., Li, Y.-Q., Yang, J., and Cui, K.-Y. (2016). Antibacterial characteristics of orange pigment extracted from Monascus pigments against Escherichia coli. Czech J Food Sci 34(3), 197-203.

Zhu, B., Qi, F., Wu, J., Yin, G., Hua, J., Zhang, Q., et al. (2019). Red yeast rice: A systematic review of the traditional uses, chemistry, pharmacology, and quality control of an important chinese folk medicine. Front Pharmacol 10(1449). doi: 10.3389/fphar.2019.01449. 
bioRxiv preprint doi: https://doi.org/10.1101/2021.03 26.437149; this version posted March 31,2021. The copyright holder for this preprint (which was not certified by peer review) is the author/funder, who has granted bioRxiv a license to display the preprint in perpetuity. It is made available under aCC-BY-NC-ND 4.0 International license.

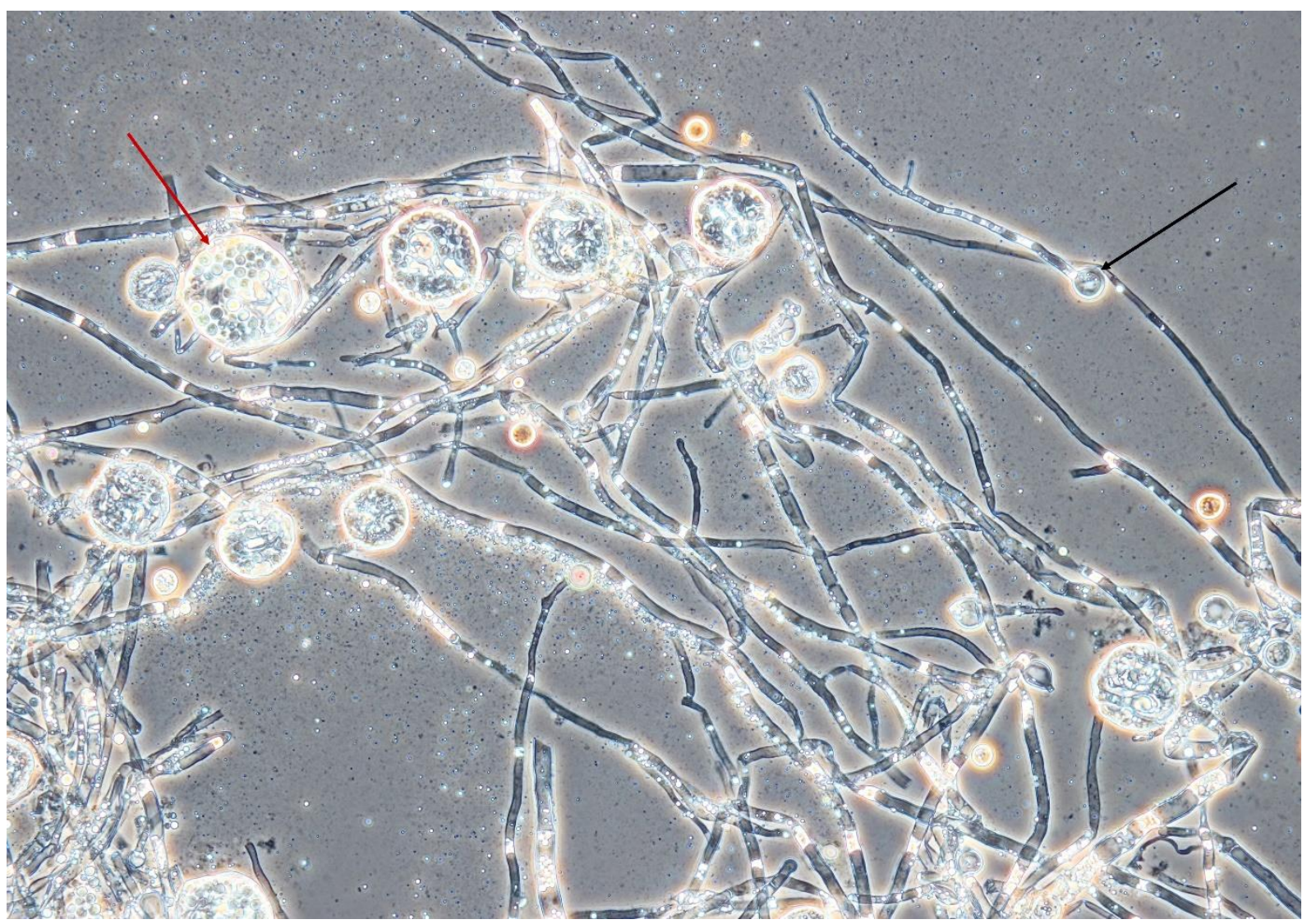

452 Fig. 1 Mycelium, conidia and cleistothecia of Monascus sp. DBM 4361

453 An example of a conidium is marked with a black arrow, the red arrow shows a cleistothecium 454 with ascospores. The specimen was prepared from the fungus grown on a PDA agar slant for 5 455 days at $30^{\circ} \mathrm{C}$; magnification was $400 \mathrm{x}$. 
bioRxiv preprint doi: $\mathrm{https}$ ://doi. org/10.1101/2021.03 26.437149. this version posted March 31,2021. The copyright holder for this preprint (which was not certified by peer review) is the author/funder, who has granted bioRxiv a license to display the preprint in perpetuity. It is made available under aCC-BY-NC-ND 4.0 International license.

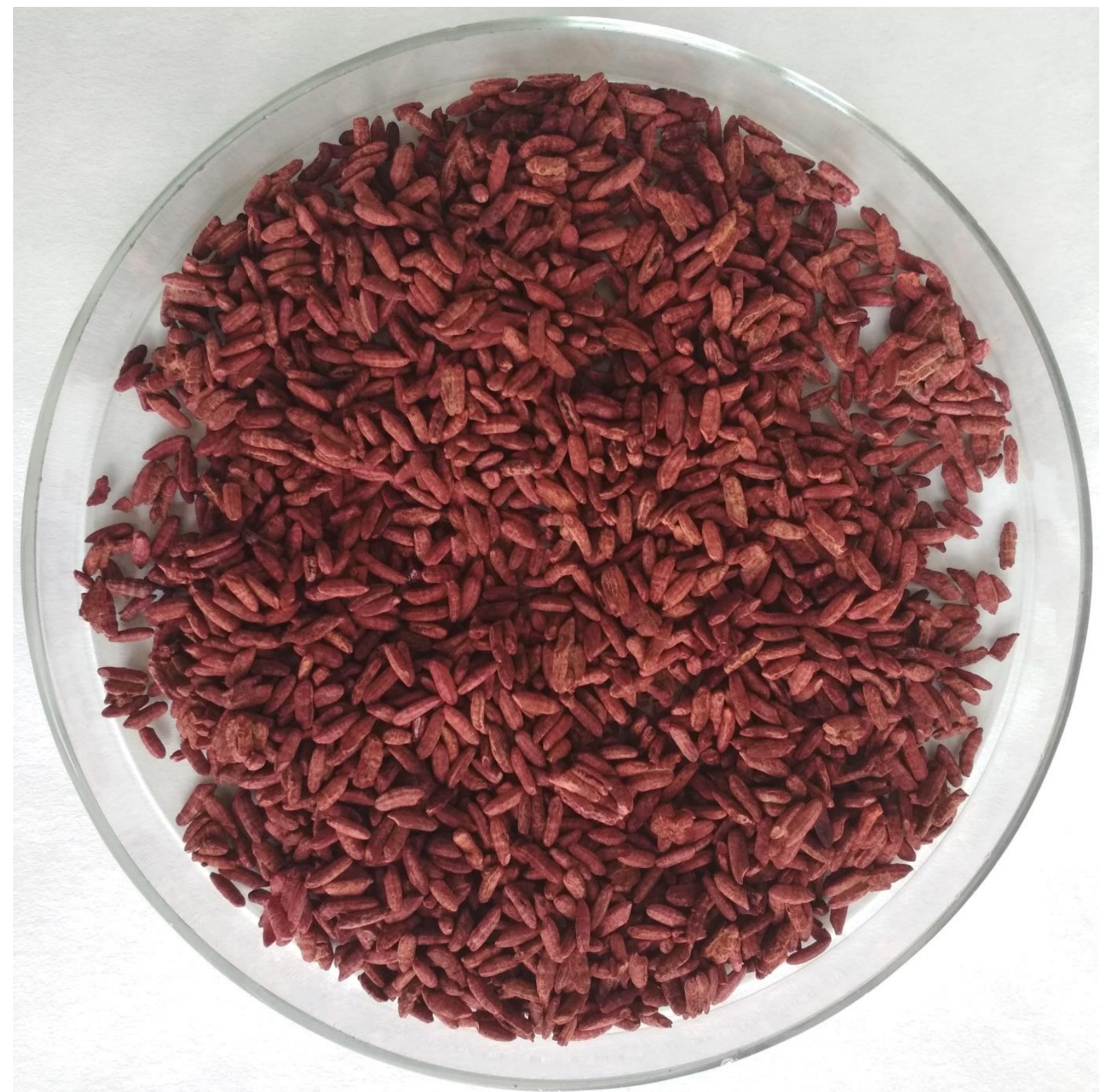




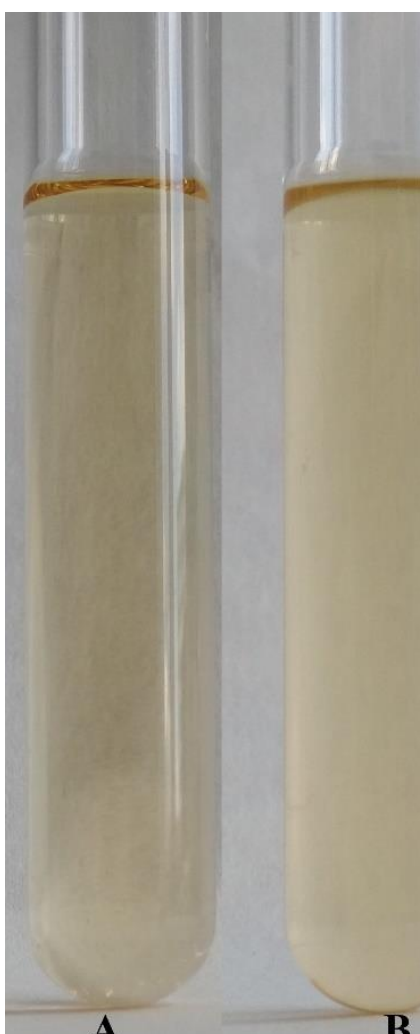

B

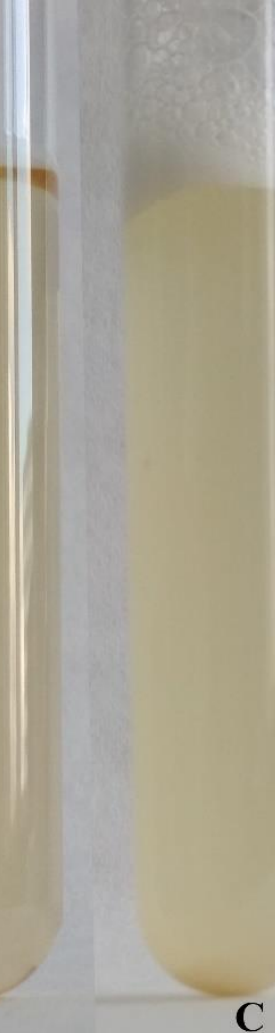

C

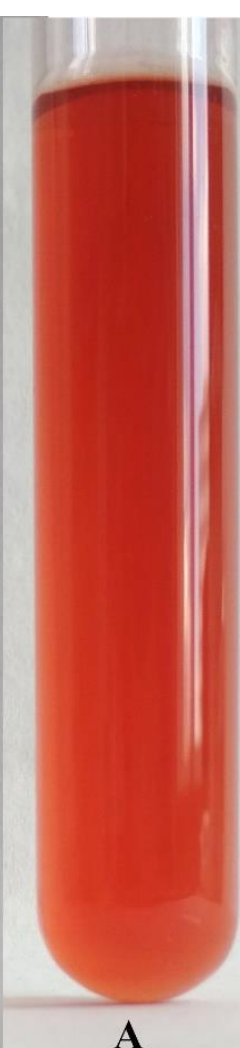

A

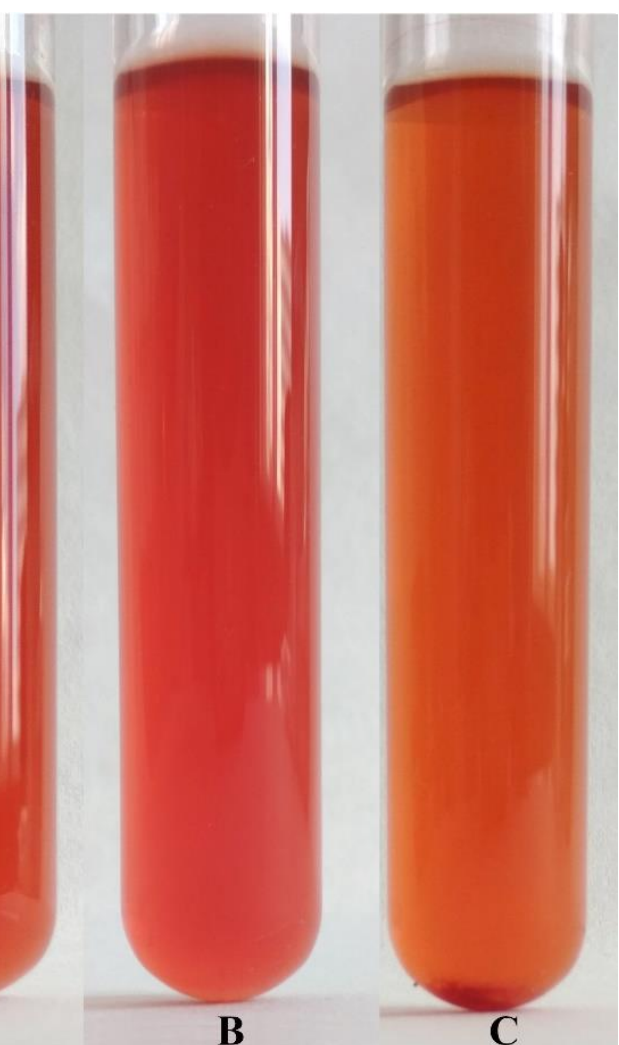

B

462 Positive control i.e. outgrowth of $C$. beijerinckii spores in TYA medium is shown on the left while suppression of spore germination after addition of RYR extract to $2 \% \mathrm{v} / \mathrm{v}$ is shown on the right. A test tube with medium was photographed prior to inoculation (A), after inoculation (B) and after $48 \mathrm{~h}$ cultivation (C) 

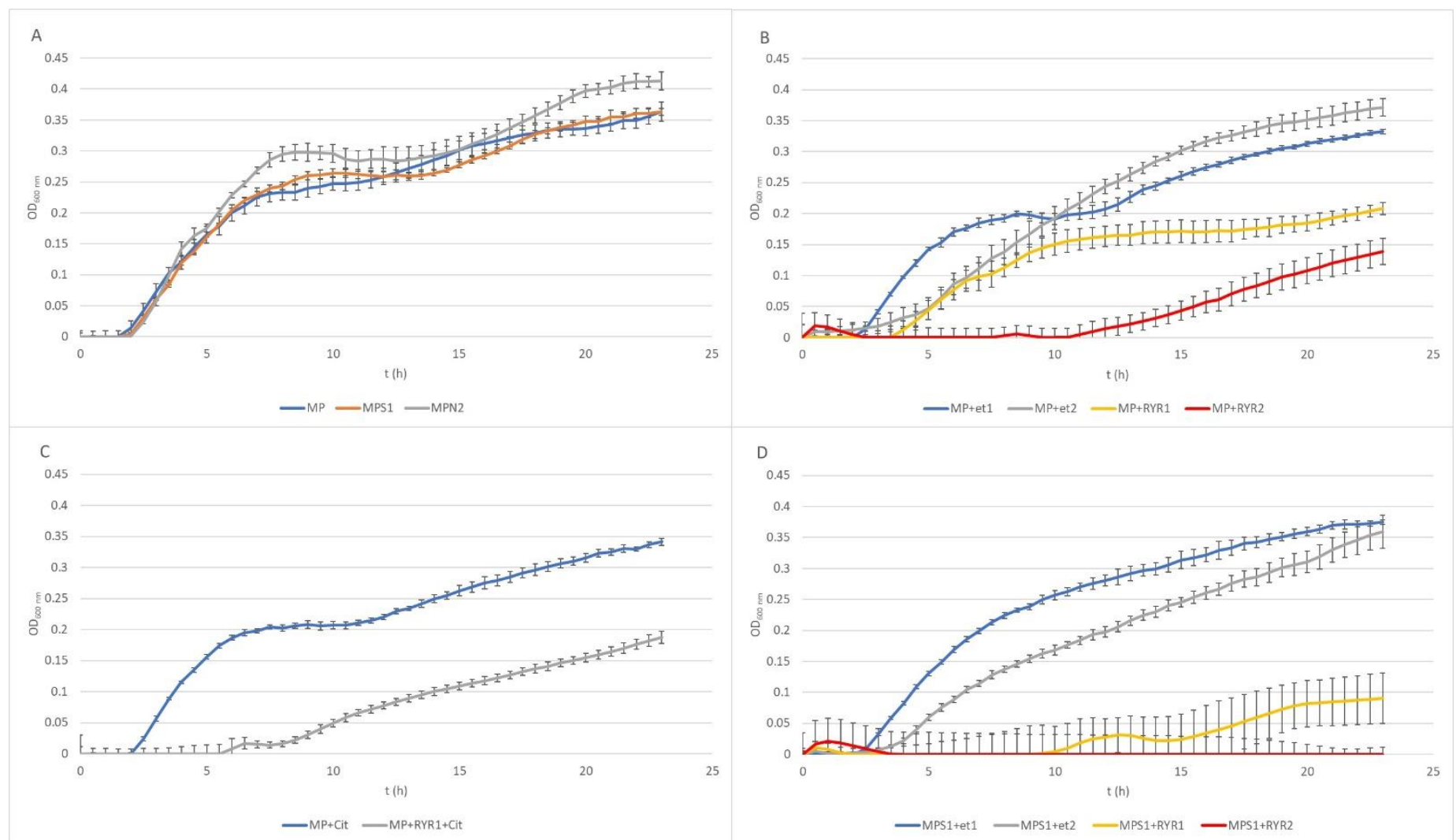

Fig. 4 Growth curves of $B$. subtilis using different compositions of culture medium (for the experiment design see Table II)

Graph A shows control experiment in MP medium and demonstrates the influence of NaCl to $1.3 \%$ w/w (MPS1) and pickling nitrite salt to $2.0 \%$ w/w (MPN2);

Graph B shows the effect of ethanol at concentrations of 1.92 and $3.84 \%$ v/v to MP medium (MP +Et1, MP + Et2) and addition of RYR ethanol extract to 1.92 and $3.84 \% \mathrm{v} / \mathrm{v}$ (MP+ RYR1, MP+RYR2)

Graph $\mathrm{C}$ shows the citrinin effect independently (MP+cit) or in combination with RYR extract (MP+RYR1+cit).

Graph D shows the combined influence of $\mathrm{NaCl}(1.3 \% \mathrm{w} / \mathrm{w})$ and ethanol (1.92 and $3.84 \% \mathrm{v} / \mathrm{v})$; (MPS1+ Et1, MPS1 +Et2) or RYR ethanol extract ( 2 and $4 \% \mathrm{v} / \mathrm{v})$; (MPS1+ RYR1, MPS1 +RYR2). 
bioRxiv preprint doi: https://doi.org/10.1101/2021 03.26.437149; this version posted March 31, 2021. The copyright holder for this preprint (which was not certified by peer review) is the author/funder, who has granted bioRxiv a license to display the preprint in perpetuity. It is made available under aCC-BY-NC-ND 4.0 International license.

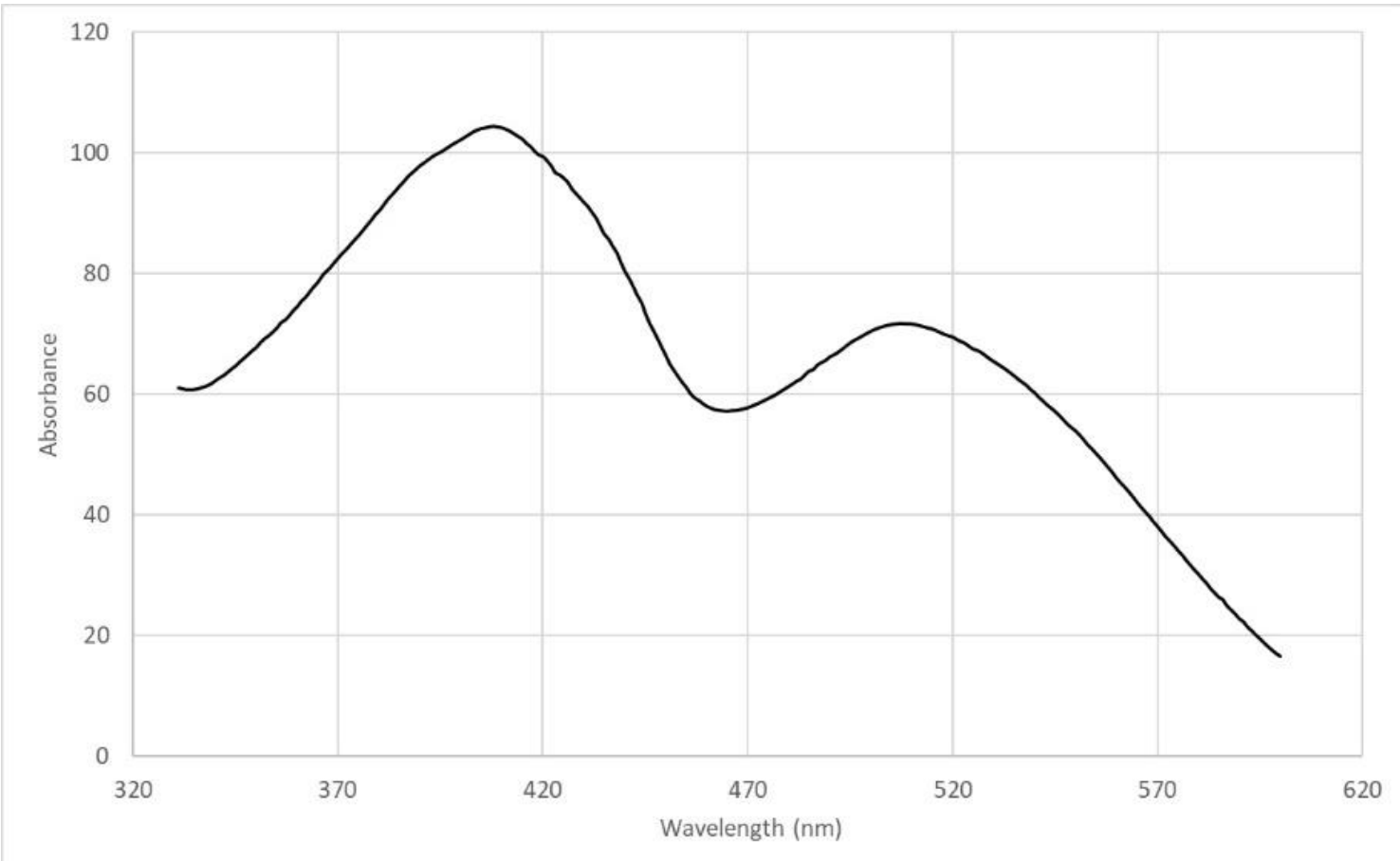




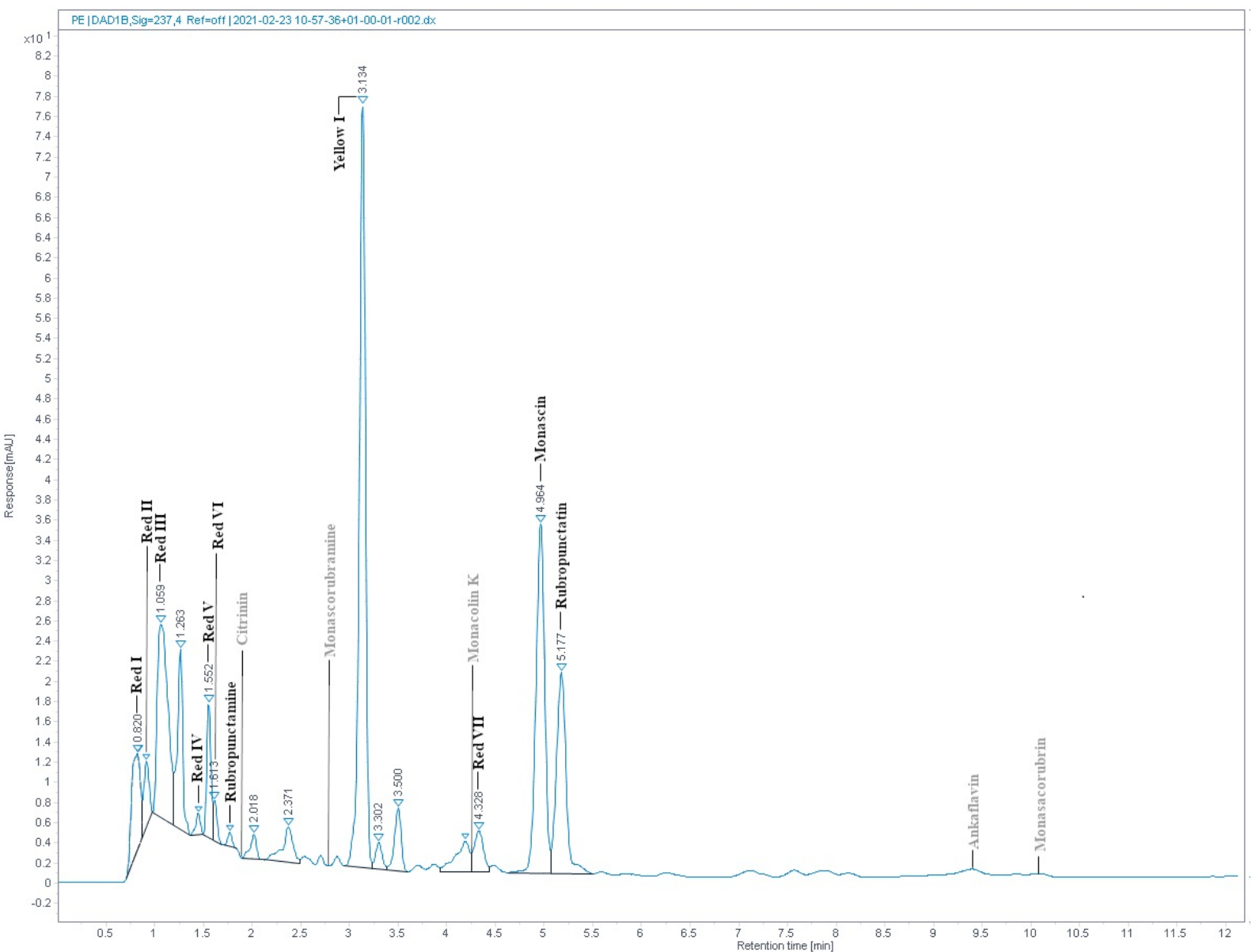
grey colour. Conditions of UHPLC analysis are given in the section 2.3. 
516 Table I. Design of $C$. beijerinckii germination assays in individual test tubes

517 TYA - unmodified TYA medium with $20 \mathrm{~g} / \mathrm{L}$ glucose; TYAS1, TYAS2 - TYA medium with

518 the addition of $1.3 \% \mathrm{w} / \mathrm{w}$ and $2.0 \% \mathrm{w} / \mathrm{w} \mathrm{NaCl}$, respectively; TYAN1, TYAN2 - TYA medium

519 with the addition of $1.3 \% \mathrm{w} / \mathrm{w}$ and $2.0 \% \mathrm{w} / \mathrm{w}$ Praganda butcher's nitrite pickling mixture $(\mathrm{K}+\mathrm{S}$

520 company, Czech Republic); TYA $+\mathrm{NaNO}_{2}$ and $\mathrm{TYA}+\mathrm{NaNO}_{3}-\mathrm{TYA}$ media with the addition

521 of $300 \mathrm{mg} / \mathrm{L} \mathrm{NaNO}$ or $\mathrm{NaNO}_{3}$; citrinin was added from stock solution, of concentration 100

$522 \mathrm{mg} / \mathrm{L}$ in dimethylsulfoxide; et - ethanol, cit - citrinin.

\begin{tabular}{|c|c|c|c|c|c|c|}
\hline & $\begin{array}{l}\text { Assay } \\
\text { component }\end{array}$ & TYA $(\mu \mathrm{L})$ & $\begin{array}{l}96 \% \\
\text { ethanol }\end{array}$ & $\begin{array}{l}\text { RYR } \\
\text { extract }\end{array}$ & $\begin{array}{l}\text { Citrinin } \\
(\mu \mathrm{L})\end{array}$ & $\begin{array}{l}\text { Inoculum } \\
\text { Heat- }\end{array}$ \\
\hline Code & $\begin{array}{l}\text { Type of } \\
\text { experiment }\end{array}$ & & $(\mu \mathrm{L})$ & $(\mu \mathrm{L})$ & & $\begin{array}{l}\text { shocked } \\
\text { spores }(\mu \mathrm{L})\end{array}$ \\
\hline TYA & $\begin{array}{l}\text { Positive } \\
\text { control }\end{array}$ & 9800 & - & - & - & 200 \\
\hline TYA & $\begin{array}{l}\text { Negative } \\
\text { control }\end{array}$ & 10000 & - & - & - & - \\
\hline TYA+et & Control & 9600 & 200 & - & - & 200 \\
\hline TYA+RYR & Test & 9600 & - & 200 & - & 200 \\
\hline TYA + cit & Test & 9780 & - & - & 20 & 200 \\
\hline TYA + RYR + cit & Test & 9580 & - & 200 & 20 & 200 \\
\hline & & $\begin{array}{l}\text { TYAS1 } \\
(\mu \mathrm{L})\end{array}$ & $\begin{array}{l}96 \% \\
\text { ethanol } \\
(\mu \mathrm{L})\end{array}$ & $\begin{array}{l}\text { RYR } \\
\text { extract } \\
(\mu L)\end{array}$ & & $\begin{array}{l}\text { Inoculum } \\
\text { Heat- } \\
\text { shocked } \\
\text { spores }(\mu \mathrm{L})\end{array}$ \\
\hline TYS1 & Test & 9800 & - & - & - & 200 \\
\hline TYAS1 + et & Control & 9600 & 200 & - & - & 200 \\
\hline TYAS1 + RYR & Test & 9600 & - & 200 & - & 200 \\
\hline & & $\begin{array}{l}\text { TYAS2 } \\
(\mu \mathrm{L})\end{array}$ & & & & $\begin{array}{l}\text { Inoculum } \\
\text { Heat- } \\
\text { shocked } \\
\text { spores }(\mu \mathrm{L})\end{array}$ \\
\hline TYAS2 & Test & 9800 & - & - & - & 200 \\
\hline & & $\begin{array}{l}\text { TYAN1 } \\
(\mu \mathrm{L})\end{array}$ & & & & $\begin{array}{l}\text { Inoculum } \\
\text { Heat- } \\
\text { shocked } \\
\text { spores }(\mu \mathrm{L})\end{array}$ \\
\hline TYAN1 & Test & 9800 & - & - & - & 200 \\
\hline & & $\begin{array}{l}\text { TYAN2 } \\
(\mu \mathrm{L})\end{array}$ & & & & $\begin{array}{l}\text { Inoculum } \\
\text { Heat- } \\
\text { shocked } \\
\text { spores }(\mu \mathrm{L})\end{array}$ \\
\hline TYAN2 & Test & 9800 & - & - & - & 200 \\
\hline & & $\begin{array}{l}\text { TYA } \\
+\mathrm{NaNO}_{2} \\
(\mu \mathrm{L})\end{array}$ & & & & $\begin{array}{l}\text { Inoculum } \\
\text { Heat- } \\
\text { shocked } \\
\text { spores }(\mu \mathrm{L})\end{array}$ \\
\hline $\mathrm{TYA}+\mathrm{NaNO}_{2}$ & Test & 9800 & - & - & - & 200 \\
\hline & & $\begin{array}{l}\text { TYA } \\
+\mathrm{NaNO}_{3} \\
(\mu \mathrm{L})\end{array}$ & & & & $\begin{array}{l}\text { Inoculum } \\
\text { Heat- } \\
\text { shocked } \\
\text { spores }(\mu \mathrm{L})\end{array}$ \\
\hline TYA+ $\mathrm{NaNO}_{3}$ & Test & 9800 & - & - & - & 200 \\
\hline
\end{tabular}


Table II Design of $B$. subtilis germination assays in individual wells of a microcultivation plate

MP - unmodified MP medium; MPS1- MP medium with addition of $1.3 \% \mathrm{w} / \mathrm{w} \mathrm{NaCl}$; MPN2 - MP medium with addition of $2.0 \% \mathrm{w} / \mathrm{w}$ Praganda butcher's nitrite pickling mixture (K+S company, Czech Republic); citrinin was added from a stock solution, of concentration $100 \mathrm{mg} / \mathrm{L}$ in dimethylsulfoxide

\begin{tabular}{|c|c|c|c|c|c|c|}
\hline & $\begin{array}{l}\text { Assay } \\
\text { component }\end{array}$ & \multirow[t]{2}{*}{$\begin{array}{l}\text { MP } \\
(\mu \mathrm{L})\end{array}$} & \multirow{2}{*}{$\begin{array}{l}96 \% \\
\text { ethanol } \\
(\mu \mathrm{L})\end{array}$} & \multirow{2}{*}{$\begin{array}{l}\text { RYR } \\
\text { extract } \\
(\mu \mathrm{L})\end{array}$} & \multirow[t]{2}{*}{$\begin{array}{l}\text { Citrinin } \\
(\mu \mathrm{L})\end{array}$} & \multirow{2}{*}{$\begin{array}{l}\text { Inoculum } \\
\text { Heat-shocked } \\
\text { spores }(\mu \mathrm{L})\end{array}$} \\
\hline Code & $\begin{array}{l}\text { Type of } \\
\text { experiment }\end{array}$ & & & & & \\
\hline MP & $\begin{array}{l}\text { Positive } \\
\text { control }\end{array}$ & 196 & - & - & - & 4 \\
\hline MP & $\begin{array}{l}\text { Negative } \\
\text { control }\end{array}$ & 200 & - & - & - & - \\
\hline MP+et1 & Control & 192 & 4 & - & - & 4 \\
\hline MP+et2 & Control & 188 & 8 & & & 4 \\
\hline MP+RYR1 & Test & 192 & - & 4 & - & 4 \\
\hline MP+RYR2 & Test & 188 & - & 8 & - & 4 \\
\hline $\mathrm{MP}+$ cit & Test & 196 & - & - & 0.8 & 4 \\
\hline \multirow[t]{2}{*}{ MP + RYR1 + cit } & Test & 192 & - & 4 & 0.8 & 4 \\
\hline & & $\begin{array}{l}\text { MPS1 } \\
(\mu \mathrm{L})\end{array}$ & $\begin{array}{l}96 \% \\
\text { ethanol } \\
(\mu \mathrm{L})\end{array}$ & $\begin{array}{l}\text { RYR } \\
\text { extract } \\
(\mu \mathrm{L})\end{array}$ & & $\begin{array}{l}\text { Inoculum } \\
\text { Heat-shocked } \\
\text { spores }(\mu \mathrm{L})\end{array}$ \\
\hline MPS1 & Test & 196 & - & - & - & 4 \\
\hline MPS1 + et1 & Control & 192 & 4 & - & - & 4 \\
\hline MPS1 + et2 & Control & 188 & 8 & - & - & 4 \\
\hline MPS1 + RYR1 & Test & 192 & - & 4 & - & 4 \\
\hline \multirow[t]{2}{*}{ MPS1 + RYR2 } & Test & 188 & - & 8 & - & 4 \\
\hline & & $\begin{array}{l}\text { MPN2 } \\
(\mu \mathrm{L})\end{array}$ & & & & $\begin{array}{l}\text { Inoculum } \\
\text { Heat-shocked } \\
\text { spores }(\mu \mathrm{L})\end{array}$ \\
\hline MPN2 & Test & 196 & - & - & - & 4 \\
\hline
\end{tabular}


Table III Results of C.beijerinckii germination assays

552 The experimental code correlates with the experimental design given in Table I. All 553 experiments were performed in triplicate, spore outgrowth observed in all 3 test tubes is marked 554 as +++, no growth as ---. *In case of dubious results, the cultivation test was repeated but if the 555 result was the same, i.e. ++- or +-- this means unreliable suppression of germination. The most 556 significant results are highlighted.

557

\begin{tabular}{|c|c|c|c|}
\hline Code & Type of experiment & Experiment description & Result \\
\hline TYA & Positive control & - & +++ \\
\hline TYA & Negative control & - & --- \\
\hline TYA+et & Control & Control ethanol addition & +++ \\
\hline TYA+RYR & Test & $\begin{array}{l}\text { Addition of RYR extract } \\
\text { in concentration } 2 \% \mathrm{v} / \mathrm{v}\end{array}$ & \begin{tabular}{|l|}
--- \\
\end{tabular} \\
\hline TYA + cit & Test & $\begin{array}{l}\text { Addition of citrinin in } \\
\text { concentration } 2000 \mu \mathrm{g} / \mathrm{kg}\end{array}$ & +++ \\
\hline TYA + RYR + cit & Test & $\begin{array}{l}\text { Combined addition of citrinin } \\
\text { in concentration } 2000 \mu \mathrm{g} / \mathrm{kg} \text { and } \\
\text { RYR in concentration } 2 \% \mathrm{v} / \mathrm{v}\end{array}$ & --- \\
\hline TYS1 & Test & $\begin{array}{l}\text { Addition of } \mathrm{NaCl} \\
\text { in concentration } 1.3 \% \mathrm{w} / \mathrm{w}\end{array}$ & $++-*$ \\
\hline TYAS1 + et & Control & $\begin{array}{l}\text { Combined addition of } \mathrm{NaCl} \\
\text { in concentration } 1.3 \% \mathrm{w} / \mathrm{w} \text { and } \\
\text { ethanol in concentration } 2 \% \mathrm{v} / \mathrm{v}\end{array}$ & --- \\
\hline TYAS1 + RYR & Test & $\begin{array}{l}\text { Combined addition of } \mathrm{NaCl} \\
\text { in concentration } 1.3 \% \mathrm{w} / \mathrm{w} \text { and } \\
\text { RYR in concentration } 2 \% \mathrm{v} / \mathrm{v}\end{array}$ & \begin{tabular}{|l|}
-- \\
\end{tabular} \\
\hline TYAS2 & Test & $\begin{array}{l}\text { Addition of } \mathrm{NaCl} \\
\text { in concentration } 2 \% \mathrm{w} / \mathrm{w}\end{array}$ & --- \\
\hline TYAN1 & Test & $\begin{array}{l}\text { Addition of nitrite pickling salt } \\
\text { in concentration } 1.3 \% \mathrm{w} / \mathrm{w}\end{array}$ & $+--*$ \\
\hline TYAN2 & Test & $\begin{array}{l}\text { Addition of nitrite pickling salt } \\
\text { in concentration } 2 \% \mathrm{w} / \mathrm{w}\end{array}$ & --- \\
\hline TYA+ $\mathrm{NaNO}_{2}$ & Test & $\begin{array}{l}\text { Addition of alone } \mathrm{NaNO}_{2} \text { in } \\
\text { concentration } 300 \mathrm{mg} / \mathrm{L}\end{array}$ & +++ \\
\hline $\mathrm{TYA}+\mathrm{NaNO}_{3}$ & Test & $\begin{array}{l}\text { Addition of alone } \mathrm{NaNO}_{2} \text { in } \\
\text { concentration } 300 \mathrm{mg} / \mathrm{L}\end{array}$ & +++ \\
\hline
\end{tabular}


572 Table IV Concentration of pigments quantified as monascin, rubropunctatin and 573 rubropunctamine equivalents added to TYA and MP media

$574 *$ Medium codes are the same as used in Tables I and II.

575

\begin{tabular}{l|l|l|l}
\hline Medium code* & $\begin{array}{l}\text { Yellow pigments } \\
\text { (concentration } \\
\text { equivalent } \\
\text { Monascin in } \\
\mathrm{mg} / \mathrm{L} \text { ) }\end{array}$ & $\begin{array}{l}\text { Orange pigments } \\
\text { (concentration } \\
\text { equivalent } \\
\text { Rubropunctatin in } \\
\mathrm{mg} / \mathrm{L} \text { ) }\end{array}$ & $\begin{array}{l}\text { Red to } \\
\text { (concentration equivalent } \\
\text { to Rubropunctamine in } \\
\mathrm{mg} / \mathrm{L})\end{array}$ \\
\hline $\begin{array}{l}\text { TYA + RYR } \\
\text { TYAS1+ RYR }\end{array}$ & 24.4 & 6.7 & \multicolumn{1}{|c}{8.2} \\
\hline $\begin{array}{l}\text { MP+ RYR1 } \\
\text { MPS1+ RYR1 }\end{array}$ & 24.4 & 6.7 & 8.2 \\
\hline $\begin{array}{l}\text { MP+ RYR2 } \\
\text { MPS1+RYR2 }\end{array}$ & 48.8 & 13.4 & 16.4 \\
\hline
\end{tabular}

